\title{
Role of Low-Impact Development in Generation and Control of Urban Diffuse Pollution in a Pilot Sponge City: A Paired-Catchment Study
}

\author{
Hongtao Zhao ${ }^{1,2, *(1)}$, Changliang Zou ${ }^{3}$, Jiang Zhao ${ }^{4}$ and Xuyong $\mathrm{Li}^{1,2}$ \\ 1 State Key Laboratory of Urban and Regional Ecology, Research Center for Eco-Environmental Sciences, \\ Chinese Academy of Sciences, Beijing 100085, China; xyli@rcees.ac.cn \\ 2 University of Chinese Academy of Sciences, Beijing 100049, China \\ 3 Sound Group Ltd., Beijing 101102,China; zcl_cumt@126.com \\ 4 China Eco-city Academy, Beijing 100048, China; zhaojiang@tsinghua-zh.org \\ * Correspondence: htzhao@rcees.ac.cn; Tel./Fax: +86-10-6284-0210
}

Received: 13 May 2018; Accepted: 14 June 2018; Published: 21 June 2018

\begin{abstract}
Low-impact development (LID) is increasingly recognized as one of the most important stormwater source controls on a small scale. However, few studies have reported how LID practices affect the generation and control of urban diffuse pollution at the scale of urban drainage units. In this study, paired conventional and LID drainage units (CDU and LDU) were used to distinguish the role of LID practices in urban sediment accumulation and release at a residential drainage units scale (about 1-2 ha). The urban sediment dynamic build-up process, amounts per unit to equilibrium, amount and percentage of urban sediment washed-off by rainfall, pollutant concentrations during rainfall-runoff processes, and discharge water volume and pollution load from drainage units were all notably different between the paired drainage units. These results indicated that (1) LID practices have a combined effect on urban sediments accumulation and release on a drainage unit scale via reduction of the source area, changes in microtopography and formation of a greater sink area; (2) landscape alterations with LID practices within a small catchment reduced and disconnected areas with impervious surfaces, subsequently reducing the kinetic energy of wash-off and transport for urban sediment; (3) LID practices exerted notable hydrological responses and water quality responses at a micro urban catchment scale by reducing the first flush load and entire process discharge load. The results presented herein will facilitate optimal design for reliable treatment performance and assessment of the effectiveness of LID practices on an urban drainage units scale.
\end{abstract}

Keywords: low impact development; urban diffuse pollution; build-up and wash-off; stormwater quality and quantity; paired catchment

\section{Introduction}

As the treatment rate of domestic sewage has risen in both China and throughout the world, urban diffuse pollution caused by urban wash-off has become the greatest threat to urban water bodies [1-7]. Scientific studies have shown that stormwater quality is mainly influenced by urban sediment wash-off during the rainfall-runoff process [8-13]. During the rainfall-runoff process, urban sediments contribute the most important sources of suspended solids (SS), heavy metals, and polyaromatic hydrocarbons (PAHs) to stormwater [14-17]. Additionally, stormwater source control has gained relevance over traditional sewer approaches because of its potential to cope with rapid urbanization and diffuse urban pollution [18-20]. Thus, a detailed understanding of the sources and mechanisms of urban sediment transport in urban surface runoff is essential for addressing stormwater source control. 
Low Impact Development (LID) is an increasingly popular method for the reduction of adverse hydrological and water quality effects of urbanization that emphasizes on-site, small-scale control of stormwater sources [21-23]. This practice utilizes distributed stormwater source control facilities (often green infrastructure) combined with green spaces and natural hydrologic features to mitigate the effects of increased impervious surfaces as well as reduce the runoff volume and peak flow [21,24-27]. The location, size, quantity, types, and different types of combinations of LID practices have important effects on the reductions in runoff volumes, peaks discharges, and pollutant loads [19,28,29]. Unfortunately, not much is known about how LID practices exert different effects on the sources and mechanisms driving urban sediment release or its transport from land to stormwater runoff in LID (bio-filtration) catchments. In contrast to conventional (piped) catchments, differences, such as the amounts of urban sediment that accumulate during dry weather, the amounts of SS that wash off during rainfall events, and the amounts of SS that are discharged to receiving water, have not yet received adequate attention [30-32]. However, understanding the changes in the sources and mechanisms driving urban sediment release and transport resulting from LID practices is critical to their optimal design to ensure reliable treatment performance and effective assessment of LID practices.

Notably, difficulties arise when distinguishing the roles of LID practices in the sources and mechanisms driving urban sediment release and transport. The first difficulty originates from differences in the spatial scales at which studies have been conducted. Specifically, the sources and mechanisms driving urban sediment release and transport from land to stormwater runoff are often investigated as large-scale processes (about $0.5-5 \mathrm{~km}^{2}$ ); in contrast, the hydrological function and pollutant removal capabilities of LID practices are generally evaluated at small scales (about $10^{2}-10^{3} \mathrm{~m}^{2}$ ) $[18,19,33]$. The second difficulty originates from differences in research focus; studies as to the hydrological function and pollutant removal capabilities of LID often focus on changes in stormwater volume and pollutants concentration between inflow and outflow on a small scale [20,34], often neglecting urban sediment build-up, wash-off, and transport, regardless of their impact. Accordingly, there is a need for a systematic study of their interaction. The last difficulty comes from the absence of suitable measurements of their interaction. This is because the complexity of urban environments is such that it is impossible to distinguish the influence of individual LID practices on the sources and mechanisms driving urban sediment release and transport [13,33]; thus, there is still a lack of systematic observation about this topic at the urban catchment scale. Many studies have shown that the paired catchment methodology is a well-established research approach for the examination of only the effects of factors of concern, eliminating extraneous data [18,22,30].

In China, source control strategies have received a great deal of attention [35]. In 2013, the Chinese government put the "sponge city" concept forward. This concept is a multi-objective integrated strategy to deal with waterlogging and urban diffuse pollution [36,37]. Current methods applied in sponge cities are still limited to LID and, to date, have concentrated on stormwater source control on a small scale [38]. The current main concern is determining how to design individual LID systems as well as methods for monitoring and evaluation of individual LID systems on a small scale in pilot sponge cities. Furthermore, existing LID programs are mainly in urban areas, where they have an important impact on the sources and transport of urban sediment [28,39]. These changes in the sources and transport of urban sediment will also influence the design for reliable treatment performance and the effectiveness of methods for assessment of LID practices. Unfortunately, this topic has not been given enough attention in China. Thus, there is an urgent need to investigate the interaction of LID practices and urban diffuse pollution on an urban catchment or a drainage unit scale for sponge city construction in China.

Given the importance and lack of the role of LID practice employed at an urban catchment with regard to the source and mechanisms of wash-off and transport, a LID (bio-filtration) catchment and a conventional (piped) catchment were selected as a paired catchment. A comparable evaluation was conducted to characterize the sources and transport of urban sediments in both catchments. The objectives of this study were to (i) quantify the amount of urban sediment that accumulated during 
dry weather, the amount of SS that washed off during rainfall events, the reduction in SS because of LID facilities, and the amounts discharged through LID facilities; (ii) quantify the effectiveness of LID practices by evaluating hydrological function and removal capabilities at a small catchment scale; (iii) examine the specific role and impact of LID practices when employed in a small urban catchment in the generation and control of urban diffuse pollution.

\section{Materials and Methods}

\subsection{Study Site Description}

Zhenjiang is one of the first 16 pilot sponge cities designated in 2014; it is a prefecture-level city in Jiangsu Province, China that lies at the intersection of the Yangtze River and the Beijing-Hangzhou Grand Canal. The mean annual temperature in the city is $15.6{ }^{\circ} \mathrm{C}$ and the average annual rainfall is $1088.2 \mathrm{~mm}$. There have been various case studies of LID construction in the city's traditional residential areas, which provide a robust foundation for this research study. In this study, two drainage units (conventional drainage unit, CDU, 1.19 ha; LID drainage unit, LDU, 1.85 ha) of a typical residential catchment were selected in the Jingkou Districts of Zhenjiang (Figures 1 and 2). On the basis of our site investigation, the two selected drainage units had many points of similairty before LDU modifications, such as land uses, spatial layout and proportion of impervious surface and green space, population density, drainage systems (combined sewer systems), street-cleaning methods and frequencies, and traffic characteristics. Thus, we assume that the CDU and LDU were paired drainage units that could distinguish the role of LID practices in urban sediment build-up, transportation, and its pollutant removal effectiveness, as well as in the reduction of runoff volume. Table 1 provides the paired catchments characteristics. Additionally, the two catchments were separated by a road whose width was less than $30 \mathrm{~m}$. A rain rainfall gauge was installed in LDU.

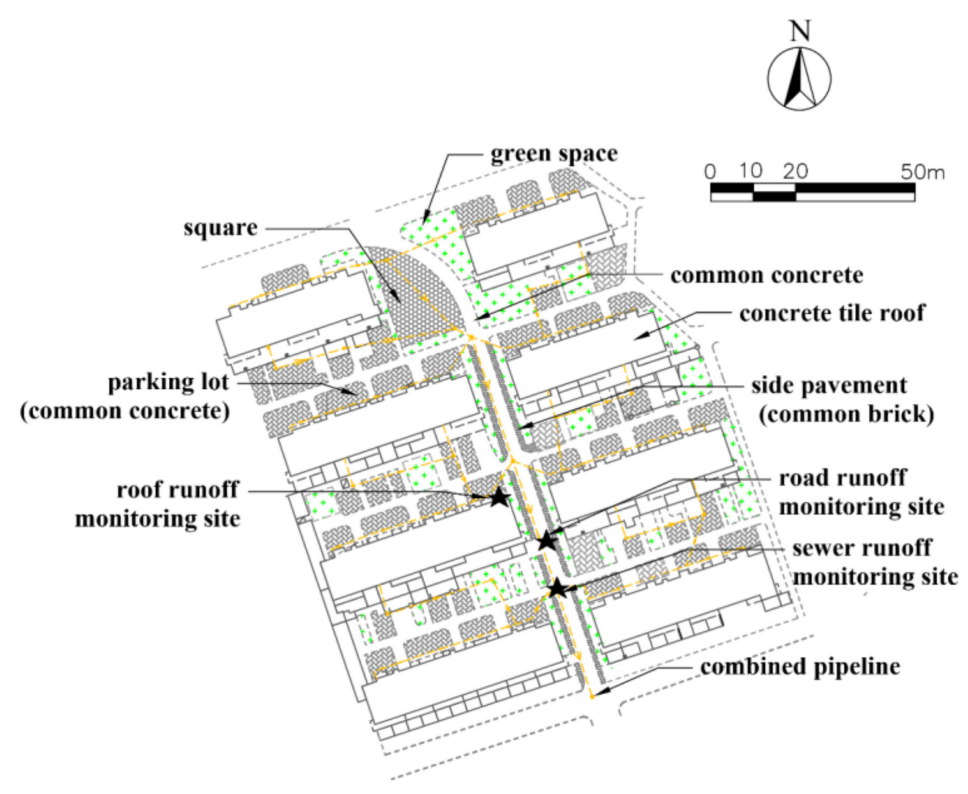

Figure 1. Conventional drainage unit (1.19 ha; roof and road runoff systems were collected by a combined pipeline and eventually fed into the sewer line). 


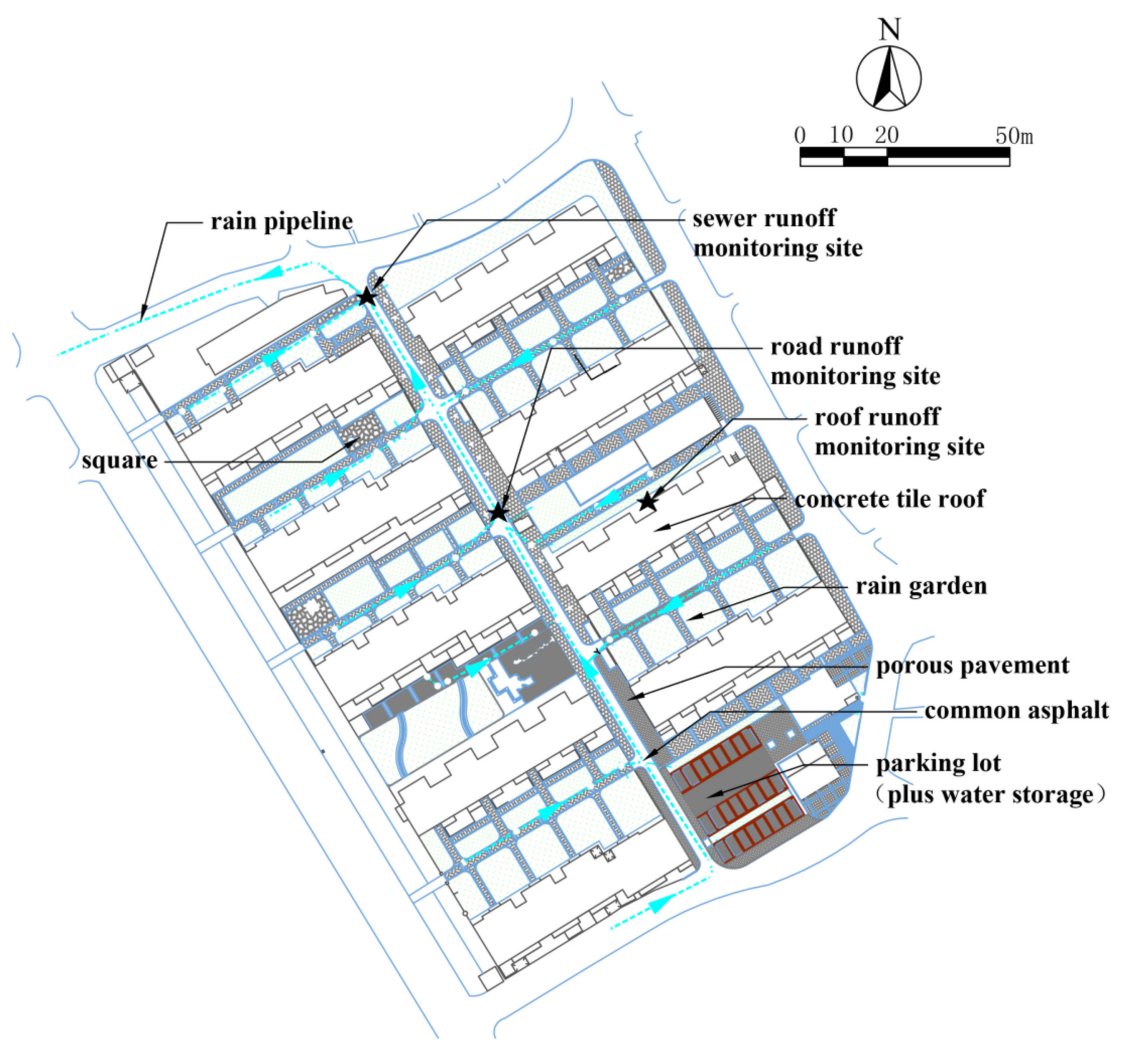

Figure 2. LID drainage unit (1.85 ha; roof and road runoff systems were collected by rain gardens and the discharge water when overflow through LID facilities occurred eventually drained into the corresponding sewer inlet nodes).

Table 1. Comparison of the composition and proportion of land uses between a paired LID (bio-filtration) and conventional (piped) drainage units (LDU and CDU).

\begin{tabular}{|c|c|c|c|c|c|}
\hline \multicolumn{3}{|c|}{$\mathrm{CDU}$} & \multicolumn{3}{|c|}{ LDU } \\
\hline Land Use & Area $\left(m^{2}\right)$ & Percentage (\%) & Land Use & Area $\left(m^{2}\right)$ & Percentage $(\%)$ \\
\hline Building (concrete tile roof) & 4680 & 39.33 & Building (concrete tile roof) & 7476 & 40.33 \\
\hline Road (common concrete) & 1430 & 12.02 & Road (common asphalt) & 465 & 2.51 \\
\hline Green space & 1750 & 14.71 & Raingarden & 4056 & 21.87 \\
\hline Side pavement (common brick) & 480 & 4.03 & Porous pavement & 4810 & 25.95 \\
\hline Square (common concrete) & 300 & 2.52 & Square (common brick) & 330 & 1.78 \\
\hline Parking lot (common concrete) & 3260 & 27.39 & $\begin{array}{l}\text { Porous pavement } \\
\text { (plus water storage) }\end{array}$ & 1400 & 7.55 \\
\hline Total area & 11,900 & 100 & Total area & 18,537 & 100 \\
\hline
\end{tabular}

\subsection{Field Observation of Urban Sediment Accumulation and Transport}

(1) Urban sediment sampling: To compare the build-up process of urban sediments on road surfaces and parking lots in the CDU and LDU, samples were collected at 1, 7, 11, and 15 days after rainfall events. Urban sediments were collected using a domestic vacuum cleaner (Philips FC 6168). A discrete sampling program was employed to collect urban sediment with 1, 7, 11, and 15 day intervals of antecedent dry periods after the last rainfall event during July and August of 2016. The sampling plot was between the curb and the middle line on the paved areas (road, parking lot, squares) as more urban sediment accumulates along the curb area because of wind and traffic turbulence. All urban sediment samples were dried at room temperature for seven days, then weighed using an electronic scale. The collected urban sediment samples were divided into nine particle sizes (<20, 20-44, 44-62, 62-105, 105-149, 149-250, 250-450, 450-1000, and 1000-2000 $\mu \mathrm{m}$ ) using an aerodynamic sifter (Retsch AS200jet, Haan, Germany). 
(2) Urban stormwater runoff sampling: Urban stormwater runoff samples were collected from the paired drainage units (CDU and LDU), including roof runoff, road runoff, parking lot runoff, and sewer runoff. Roof runoff was collected from the outlet of the building downpipe using a pan. Road runoff and parking lot runoff were collected from the selected catch basin or before flowing into the LID practice using a pan. Sewer runoff was collected from the drainage outlet using a $1 \mathrm{~L}$ plastic beaker. The rainfall dates, volumes, and intensities can be found in Table 2. To obtain the runoff volume, each stormwater runoff sample was collected every $5 \mathrm{~min}$ for the initial $10 \mathrm{~min}$ after runoff generation. Each stormwater runoff sample was then collected every $10 \mathrm{~min}$ for the next $30 \mathrm{~min}$. Other samples were collected every $20 \mathrm{~min}$ until runoff ceased. The time and volume of each sample was recorded to determine the total runoff volume.

(3) The retention load and rate: The retention load for a certain pollutant was calculated as the difference of the pollutant discharge load between LID and conventional drainage units. The retention rate was the percentage of the retention load in pollutant discharge load in conventional drainage unit.

Table 2. Rainfall characteristics from July to August in 2016.

\begin{tabular}{cccccc}
\hline Date of Rain Event & Rainfall (mm) & Duration (min) & $\begin{array}{c}\text { Average Intensity } \\
\text { (mm/min) }\end{array}$ & $\begin{array}{c}\text { Maximum Intensity } \\
\text { (mm/min) }\end{array}$ & $\begin{array}{c}\text { Antecedent Dry } \\
\text { Weather Period (d) }\end{array}$ \\
\hline 13 July 2016 & 18.9 & 25 & 0.756 & 2.13 & 7 \\
2 August 2016 & 2.8 & 30 & 0.093 & 0.40 & 16 \\
3 August 2016 & 39.0 & 60 & 0.65 & 0.84 & 1 \\
6 August 2016 & 8.7 & 30 & 0.29 & 0.80 & 3 \\
\hline
\end{tabular}

\subsection{Analytical Methods}

The collected stormwater runoff samples were preserved at $4{ }^{\circ} \mathrm{C}$ until analysis. Total suspended solids (TSS), chemical oxygen demand (COD), ammonia $\left(\mathrm{NH}_{4}{ }^{+}-\mathrm{N}\right)$, total nitrogen (TN), and total phosphorous (TP) in runoff water were analyzed using 2540-TSS D, 5520-COD C, 4500- $\mathrm{NH}_{3} \mathrm{~F}, 4500-\mathrm{N}$ $\mathrm{C}$ and 4500-P E in the Standard Methods [40].

\section{Results}

\subsection{Effects of LID Practices on Urban Sediments Build-Up Process}

Variations in the amounts of urban sediments during the four dry weather periods $(1,7,11,15$ days) are shown in Figure 3. The dynamic accumulation process in the LDU was clearly different from that in the CDU. Both road surfaces and parking lots in the CDU contained larger amounts of sediments than those in the LDU. Furthermore, the amount of sediment retained by the road surfaces and parking lots increased with increasing antecedent dry weather periods in the CDU, while the sediment build-up on road surfaces and parking lots in the LDU reached their equilibrium (road surfaces, $10 \mathrm{~g} / \mathrm{m}^{2}$; parking lots, $4.3 \mathrm{~g} / \mathrm{m}^{2}$ ) at around seven days after the last rainfall event. On the basis of our on-site investigation, the construction of LID facilities changed the original relatively smooth ground at a drainage unit scale (hectare scale) and formed several tetragonal or strips of sunken structure. These sunken structures had a greater ability to retain larger amounts of urban sediment than common impervious surfaces and traditional high green space, which changed the spatial distribution patterns and dynamic cumulative equilibrium of urban sediments in the residential catchment. Additionally, the sediment build-up in the CDU was different from that on the main traffic road surfaces because conventional residential areas have no vehicle-induced or other turbulence; therefore, the sediment particles steadily accumulate until the next rainfall event. These results indicate that LID facilities could retain urban sediment by changing the original micro-topography. 

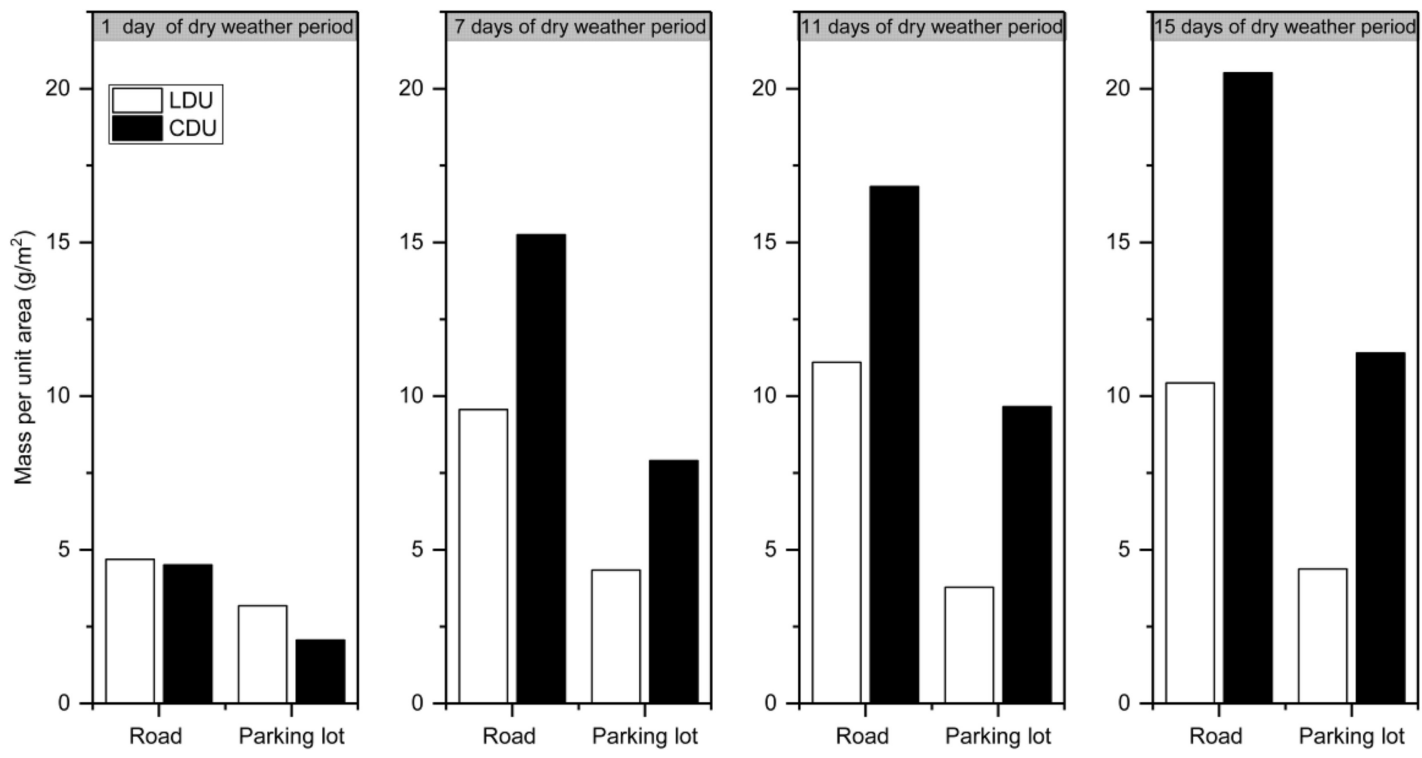

Figure 3. The accumulation process of urban sediments during dry weather in the LID and conventional residential catchment. LDU $=$ LID residential drainage unit; $\mathrm{CDU}=$ conventional residential drainage unit.

\subsection{Effects of LID on Variations in Urban Sediment Amount before and After Rainfall Events}

The variations in sediment load one day before and after a natural rainfall event were observed in the LDU and CDU concurrently (Figure 4). The sediment loads on road surfaces in the LDU and CDU were reduced significantly by $5.7 \mathrm{~g} / \mathrm{m}^{2}$ (from 10.4 to $4.7 \mathrm{~g} / \mathrm{m}^{2}$ ) and $16.0 \mathrm{~g} / \mathrm{m}^{2}$ (from 20.5 to $4.5 \mathrm{~g} / \mathrm{m}^{2}$ ) during the heavy rain event (3 August, $39.0 \mathrm{~mm}$ ), respectively. Furthermore, the sediment wash-off percentages $\left(F_{w}, \%\right)$ from road surfaces were $55 \%$ and $78 \%$ in the LDU and CDU, respectively. For parking lots, the sediment amounts in the LDU and CDU were also reduced significantly by $1.2 \mathrm{~g} / \mathrm{m}^{2}$ (from 4.4 to $3.2 \mathrm{~g} / \mathrm{m}^{2}$ ) and $9.3 \mathrm{~g} / \mathrm{m}^{2}$ (from 11.4 to $2.1 \mathrm{~g} / \mathrm{m}^{2}$ ), respectively. The sediment wash-off percentages $\left(F_{w}, \%\right)$ from the parking lot were $27 \%$ and $82 \%$ in the LDU and CDU, respectively. Generally, LID facilities played a significant role in sediment release and transport in stormwater runoff. During runoff sampling, we found road surfaces and parking lots in the CDU to generally be the confluence and transmission area of rainwater from roofs and other areas, while these surfaces in the LDU received no other rainwater. As a result, the same rainfall event in the CDU can produce high enough kinetic energy to wash-off these urban sediments, which may explain why urban sediment retained by the CDU could be more easily mobilized by stormwater runoff than that in the LDU. Our results also indirectly confirm that LID facilities on a small scale can be efficient at reducing peak discharges and runoff volume. 

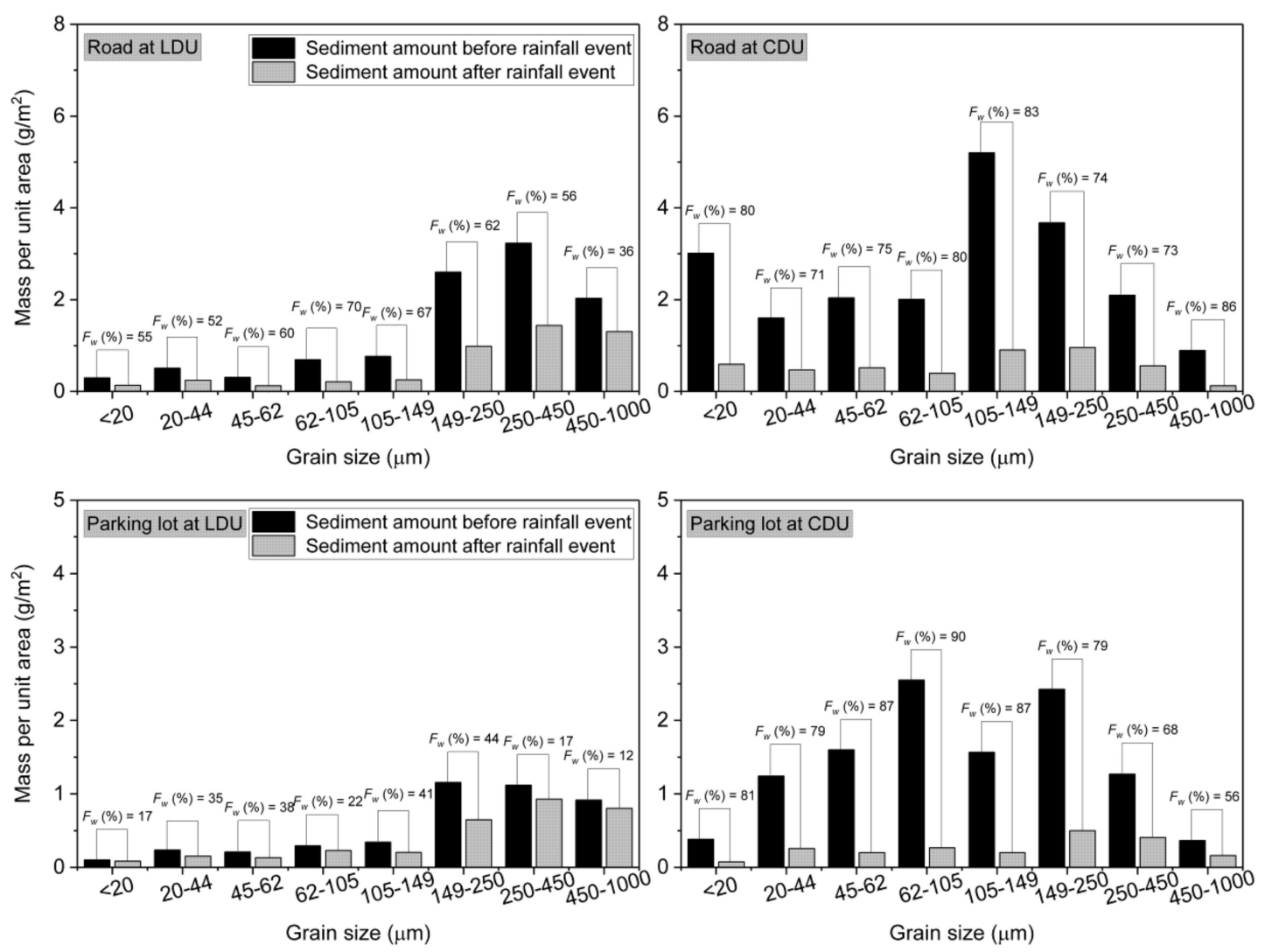

Figure 4. Variations in urban sediment amount before and after rainfall events. LDU = LID residential drainage unit; $C D U$ = conventional residential drainage unit.

\subsection{Effects of LID on Changes in the Concentration of Pollutants During the Rainfall-Runoff Process}

To compare the effects of LID practices on the reduction in SS and pollutants concentration during the rainfall-runoff process, the concentrations of TSS and other pollutants were investigated in the LDU and CDU. During the two natural rain events, the CDU generally had higher TSS and other pollutant concentrations than the LDU (Figure 5). Furthermore, there were notable differences in the changes in TSS and other pollutants concentrations during the rainfall-runoff process between the LDU and CDU. The concentrations of TSS, COD and TP decreased more sharply in the CDU during the initial period of the rainfall-runoff process than in the LDU. For example, SS concentrations in the CDU decreased sharply from $1490 \mathrm{mg} / \mathrm{L}$ and $975 \mathrm{mg} / \mathrm{L}$ to $216 \mathrm{mg} / \mathrm{L}$ and $220 \mathrm{mg} / \mathrm{L}$, respectively, in the first $20 \mathrm{~min}$ during the two rainfall events $(39 \mathrm{~mm}, 1 \mathrm{~h} ; 8.7 \mathrm{~mm}, 0.5 \mathrm{~h})$. In contrast, those in the LDU decreased from $390 \mathrm{mg} / \mathrm{L}$ and $272 \mathrm{mg} / \mathrm{L}$ to $68 \mathrm{mg} / \mathrm{L}$ and $82 \mathrm{mg} / \mathrm{L}$, respectively. A reasonable explanation for this is that lower initial sediment load and smaller wash-off ability resulted from the reduction in peak flow and flow volume induced by the LID when compared with conventional catchments. These results imply that LID practices have a combined effect on the stormwater runoff pollution via the reduction of kinetic energy to wash-off pollutants during rainy weather and by the reduction of the initial sediment accumulation load during dry weather. Additionally, this combined effect of LID may increase with increased rainfall intensity. 

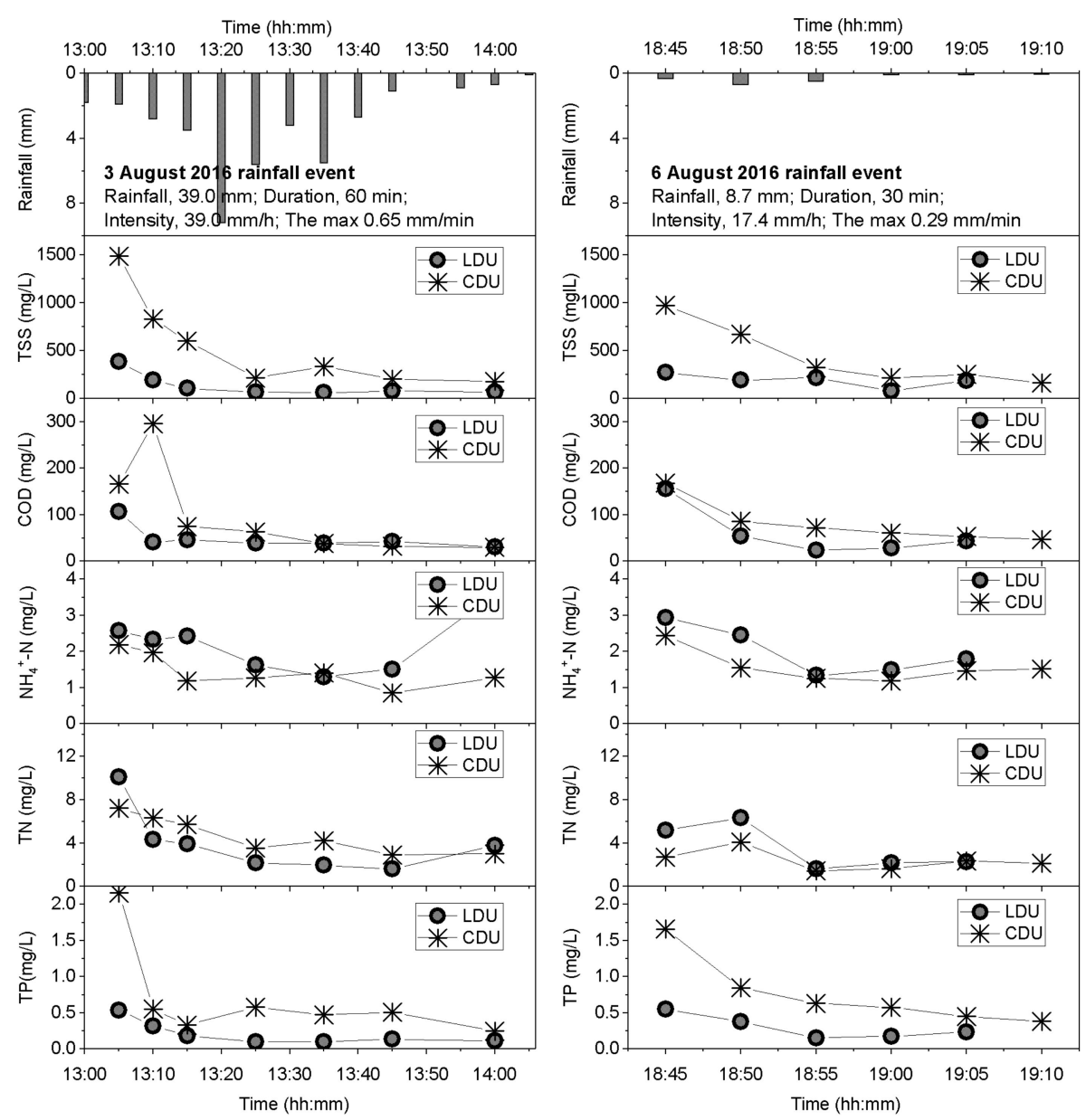

Figure 5. Variations of TSS and other pollutant concentrations during the rainfall-runoff process. $\mathrm{LDU}=\mathrm{LID}$ residential drainage unit; $\mathrm{CDU}=$ conventional residential drainage unit.

\subsection{Effects of LID on the Reduction in Runoff Volume, Pollutant Concentrations, and Load at the Drainage Units Scale}

The abilities of LID practices to reduce pollutants and runoff retention were investigated during two natural events ( $39 \mathrm{~mm}, 1 \mathrm{~h} ; 8.7 \mathrm{~mm}, 0.5 \mathrm{~h}$ ) (Figure 6). We collected the discharge water samples and measured their volumes at the outlets of the paired drainage units. In contrast to the CDU, we found the LID practices effectively reduced runoff volume, duration of elevated outflow rates, and pollutants export. For the small rainfall event $(8.7 \mathrm{~mm}, 0.5 \mathrm{~h})$, there was no discharge flow from the LDU to sewer pipes, indicating that LID practices remove all pollutants and retain all runoff water on sites. For the heavy rainfall event $(39.0 \mathrm{~mm}, 1.0 \mathrm{~h}$ ), LID practices led to a $95 \%$ reduction in runoff volume per unit area in contrast to the CDU and led to a reduction in the concentrations of pollutants. Specifically, the TSS retention was $78.6 \%$, COD retention was $88.2 \%, \mathrm{NH}^{4+}-\mathrm{N}$ retention was $65.0 \%$, TN retention was $78.7 \%$, and TP retention was $80.2 \%$. These results were consistent with those of many other LID investigations [22,41]. It also confirmed that LID practices are effective for pollutants reduction and runoff retention at the drainage unit scale. The excellent performance of the LID in the mitigation of runoff volumes and pollution load was likely because of an overdesign of the LID, which provided sufficient detention capability in the underground detention chamber and the infiltration trenches to capture the 80 -mm storm event. 


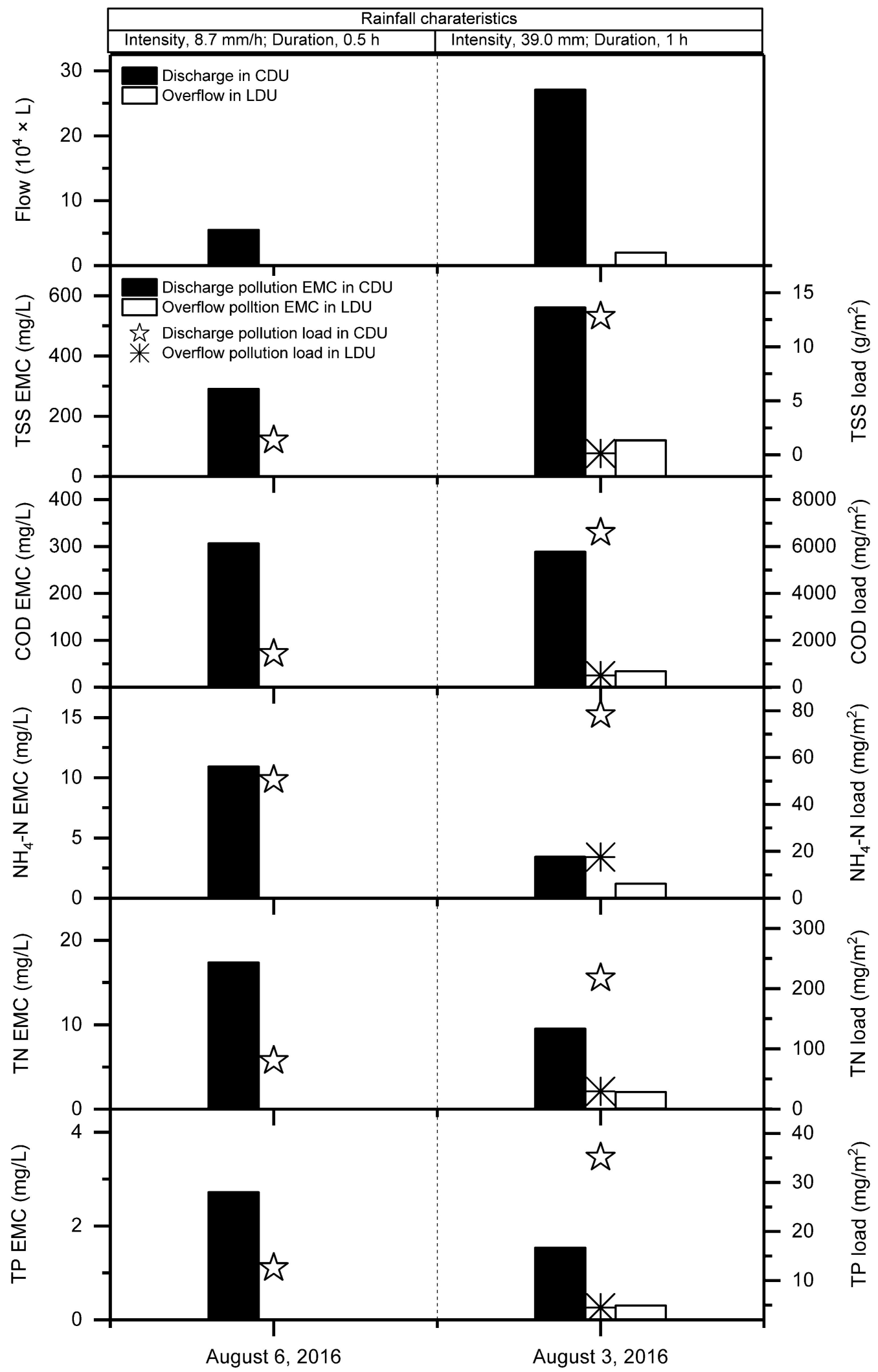

Date (day) for rainfall event

Figure 6. Role of LID practices in the reduction of runoff volume, pollutants concentration, and load at the drainage unit scale. LDU $=$ LID residential drainage unit; CDU = conventional residential drainage unit. 


\section{Discussions}

\subsection{The Role of LID Practices During the Entire Process of Urban Sediment Accumulation and Release at} a Micro Urban Catchment Scale

Urban residential drainage units at the hectare scale are one of the most important components of urban catchments. Thus, urban sediment accumulation and release in residential drainage units play an important role in urban runoff water quality and pollutant loads. Many researchers agree that urban sediment accumulation and release are affected by various factors including initial sediment load, rainfall intensity, rainfall energy, sediment properties, run-off shear stress, types and composition of impervious areas, microtopography, and surface roughness [11,42-46]. Currently, the impervious surface alterations in response to LID practices within a micro urban catchment may significantly change the factors above. However, the role of LID practices in the entire process of urban sediment accumulation and release in a micro urban catchment has seldom been studied. In this study, the total impervious area decreased from $85 \%$ to $42 \%$ due to the construction of LID practices (Table 1) in the LDU, and many urban sediments accumulation source areas were converted into sink areas. They also have an important influence on microtopography at the residential drainage unit scale and are often designed as sunken structures located below ground that can retain and attenuate urban sediment and inhibit and trap runoff water. Furthermore, the remaining impervious areas were all disconnected by LID practices, resulting in rainfall in the LDU producing lower kinetic energy. This led to urban sediment wash-off because of the disconnected impervious areas, increased infiltration, and greater retention abilities. There was also an important influence on urban accumulation amount and the period length of dynamic equilibrium in the LDU. The urban sediment amounts and the period length of dynamic equilibrium in the LDU were notably lower and shorter than those in the CDU (Figure 3). Generally, the response of the entire generation of urban diffuse pollution at a micro urban catchment scale is a combination of changes in urban sediment accumulation and release.

\subsection{Effect of LID Practices on Hydrologic Responses and Water Quality in a Micro Urban Catchment}

The effects of LID practice on hydrologic responses and water quality in micro urban catchments have seldom been studied. Many investigations have revealed that the hydrological performances were scale dependent, and that micro traditional urban catchments have more sensitive rainfall-runoff responses because of their limited drainage areas and shorter drainage lengths [47-49]. Thus, landscape alterations with LID practices within them will result in more prominent runoff changes than if similar changes were made in a larger watershed. In this study, paired drainage units (CDU and LDU) were compared with respect to hydrology and water quality. In contrast to CDUs that are designed to quickly move stormwater off impervious surfaces [30,50], we found that $85 \%$ of CDUs had directly connected to an impervious area, while LID practices disconnected all impervious areas and significantly reduced direct runoff discharge into stormwater pipelines in the LDU. Additionally, the LDU had an overdesigned system capable of capturing $80.6 \mathrm{~mm}$ stormwater (Table 3) to prevent urban waterlogging. These characteristics greatly changed the hydrological performance of imperviousness in a micro urban catchment and were efficient at reducing peak discharges and runoff volume. The LDU produced pollutant loadings were less than $5 \%$ of those in the CDU, indicating that LID practices are very effective at controlling urban sediments delivery from source areas and promoting on-site infiltration in a micro catchment. 
Table 3. Theoretical storage capacity of LID system at a residential drainage unit scale.

\begin{tabular}{|c|c|c|c|c|c|}
\hline LID Facilities & $\begin{array}{l}\text { Facilities } \\
\text { Area } / \mathrm{m}^{2}\end{array}$ & $\begin{array}{c}\text { Control } \\
\text { Catchment } / \mathrm{m}^{2}\end{array}$ & Equation & $\begin{array}{l}\text { Theoretical } \\
\text { Storage } / \mathrm{m}^{3}\end{array}$ & $\begin{array}{c}\text { Control } \\
\text { Rainfall } / \mathrm{mm}\end{array}$ \\
\hline Rain garden ${ }^{a}$ & 4056 & 12,327 & $\begin{array}{c}V r=A_{f} H_{m}+R Z M F(S A T-F C)+ \\
L M S \times p\end{array}$ & 843.6 & 68.4 \\
\hline Porous pavement ${ }^{b}$ & 4810 & 4810 & $V p=A_{f} H_{m} \times p$ & 432.9 & 90 \\
\hline Parking lot (plus water storage) ${ }^{\mathrm{c}}$ & 1400 & 1400 & $V w=A_{f} H_{m} \times p+V_{s}$ & 218 & 155.7 \\
\hline Total & 10,266 & 18,537 & & 1494.5 & 80.6 \\
\hline
\end{tabular}

a $V r$, storage volume, $\mathrm{m}^{3} ; A_{f} H_{m}$, reservoir layer volume, $4056 \times 0.1 \mathrm{~m}^{3} ; R Z M F$, root zone packing volume, $4056 \times 0.6 \times 0.6 \mathrm{~m}^{3}$; SAT, soil moisture content in saturated soil, 50\%; FC, field capacity, 30\%; LMS, lower packing layer volume, $4056 \times 0.4 \times 0.3 \mathrm{~m}^{3} ; p$, gravel layer porosity, $30 \%$. b $V p$, storage volume, $\mathrm{m}^{3} ; A_{f} H_{m}$, gravel layer volume, $4810 \times 0.3 \mathrm{~m}^{3} ; p$, gravel layer porosity, $30 \%$. ${ }^{c} V w$, storage volume, $\mathrm{m}^{3} ; A_{f} H_{m}$, gravel layer volume, $1400 \times 0.4 \mathrm{~m}^{3} ; p$, gravel layer porosity, $30 \%$. Vs, storage module volume, $50 \mathrm{~m}^{3}$.

\section{Conclusions}

In this study, we investigated the role of low-impact development in the generation and control of urban diffuse pollution within paired micro urban drainage units. The urban sediment accumulation process, the characteristics of its removal by rainfall-runoff, water quality of surface runoff, and discharge loads were comparable between the paired urban drainage units. On the basis of our findings, the following conclusions can be drawn:

(1) LID practices have an important influence on urban sediment dynamic build-up processes and amounts per unit reaching its equilibrium via reductions in source area, changing microtopography, and formation of more sink areas.

(2) LID practices have an important influence on urban sediment wash-off and transport processes via disconnection of impervious surface areas followed by reductions in the kinetic energy of wash-off and transport.

(3) LID practices have notable hydrologic responses and water quality responses at the micro urban catchment level by reducing the first flush load and entire process discharge load.

Author Contributions: H.Z. designed the research, statistical analysis and wrote the manuscript. C.Z. conducted observations and data analysis of field experiments. J.Z. and X.L. provided strategic advice and comments on the manuscript.

Funding: Funding was provided by the National Key Research and Development of China (No. 2017YFC0505800), the National Natural Science Foundation of China (No. 41171395), and the Major Science and Technology Program for Water Pollution Control and Treatment (No. 2015ZX07206-006-02).

Conflicts of Interest: The authors declare no conflict of interest.

\section{References}

1. Zhao, H.T.; Zhao, J.; Yin, C.Q.; Li, X.Y. Index models to evaluate the potential metal pollution contribution from washoff of road-deposited sediment. Water Res. 2014, 59, 71-79. [CrossRef] [PubMed]

2. Li, Y.X.; Song, N.N.; Yu, Y.; Yang, Z.F.; Shen, Z.Y. Characteristics of PAHs in street dust of Beijing and the annual wash-off load using an improved load calculation method. Sci. Total Environ. 2017, 581, 328-336. [CrossRef] [PubMed]

3. Zhao, J.Q.; Chen, Y.; Hu, B.; Yang, W.J. Mathematical Model for Sediment Wash-Off from Urban Impervious Surfaces. J. Environ. Eng. 2016, 142, 8. [CrossRef]

4. Kayhanian, M.; Fruchtman, B.D.; Gulliver, J.S.; Montanaro, C.; Ranieri, E.; Wuertz, S. Review of highway runoff characteristics: Comparative analysis and universal implications. Water Res. 2012, 46, 6609-6624. [CrossRef] [PubMed]

5. Egodawatta, P.; Thomas, E.; Goonetilleke, A. Understanding the physical processes of pollutant build-up and wash-off on roof surfaces. Sci. Total Environ. 2009, 407, 1834-1841. [CrossRef] [PubMed]

6. Al Ali, S.; Bonhomme, C.; Dubois, P.; Chebbo, G. Investigation of the wash-off process using an innovative portable rainfall simulator allowing continuous monitoring of flow and turbidity at the urban surface outlet. Sci. Total Environ. 2017, 609, 17-26. [CrossRef] [PubMed] 
7. United States Environmental Protection Agency (USEPA). National Water Quality Inventory; 2000 Report, EPA-841-R-02-001; Office of Water: Washington, DC, USA, 2002.

8. Hong, Y.; Bonhomme, C.; Le, M.H.; Chebbo, G. A new approach of monitoring and physically-based modelling to investigate urban wash-off process on a road catchment near Paris. Water Res. 2016, 102, 96-108. [CrossRef] [PubMed]

9. Bai, B.; Li, J. Sediment Wash-Off from an Impervious Urban Land Surface. J. Hydrol. Eng. 2013, 18, 488-498. [CrossRef]

10. Wicke, D.; Cochrane, T.A.; O'Sullivan, A. Build-up dynamics of heavy metals deposited on impermeable urban surfaces. J. Environ. Manag. 2012, 113, 347-354. [CrossRef] [PubMed]

11. Vaze, J.; Chiew, F.H.S. Nutrient loads associated with different sediment sizes in urban stormwater and surface pollutants. J. Environ. Eng. 2004, 130, 391-396. [CrossRef]

12. Lau, S.L.; Stenstrom, M.K. Metals and PAHs adsorbed to street particles. Water Res. 2005, 39, $4083-4092$. [CrossRef] [PubMed]

13. De Miguel, E.; Llamas, J.F.; Chacon, E.; Mazadiego, L.F. Sources and pathways of trace elements in urban environments: A multi-elemental qualitative approach. Sci. Total Environ. 1999, 235, 355-357. [CrossRef]

14. Zhao, H.T.; Chen, X.F.; Hao, S.N.; Jiang, Y.; Zhao, J.; Zou, C.L.; Xie, W.X. Is the wash-off process of road-deposited sediment source limited or transport limited? Sci. Total Environ. 2016, 563, 62-70. [CrossRef] [PubMed]

15. Sansalone, J.J.; Kim, J.Y. Transport of particulate matter fractions in urban source area pavement surface runoff. J. Environ. Qual. 2008, 37, 1883-1893. [CrossRef] [PubMed]

16. Jartun, M.; Ottesen, R.T.; Steinnes, E.; Volden, T. Runoff of particle bound pollutants from urban impervious surfaces studied by analysis of sediments from stormwater traps. Sci. Total Environ. 2008, 396, 147-163. [CrossRef] [PubMed]

17. Sutherland, R.A.; Tack, F. M.G.; Ziegler, A.D. Road-deposited sediments in an urban environment: A first look at sequentially extracted element loads in grain size fractions. J. Hazard. Mater. 2012, 225, 54-62. [CrossRef] [PubMed]

18. Petrucci, G.; Rioust, E.; Deroubaix, J.F.; Tassin, B. Do stormwater source control policies deliver the right hydrologic outcomes? J. Hydrol. 2013, 485, 188-200. [CrossRef]

19. Martin-Mikle, C.J.; de Beurs, K.M.; Julian, J.P.; Mayer, P.M. Identifying priority sites for low impact development (LID) in a mixed-use watershed. Landsc. Urban Plan. 2015, 140, 29-41. [CrossRef]

20. Li, L.Q.; Davis, A.P. Urban Stormwater Runoff Nitrogen Composition and Fate in Bioretention Systems. Environ. Sci. Technol. 2014, 48, 3403-3410. [CrossRef] [PubMed]

21. Elliott, A.H.; Trowsdale, S.A. A review of models for low impact urban stormwater drainage. Environ. Model. Softw. 2007, 22, 394-405. [CrossRef]

22. Eckart, K.; McPhee, Z.; Bolisetti, T. Performance and implementation of low impact development-A review. Sci. Total Environ. 2017, 607, 413-432. [CrossRef] [PubMed]

23. Shafique, M.; Kim, R. Low Impact Development Practices: A Review of Current Research and Recommendations for Future Directions. Ecol. Chem. Eng. S 2015, 22, 543. [CrossRef]

24. Dietz, M.E. Low impact development practices: A review of current research and recommendations for future directions. Water Air Soil Pollut. 2007, 186, 351-363. [CrossRef]

25. Palla, A.; Gnecco, I. Hydrologic modeling of Low Impact Development systems at the urban catchment scale. J. Hydrol. 2015, 528, 361-368. [CrossRef]

26. Coffman, L.S. Low-impact development: An alternative stormwater management technology. In Handbook of Water Sensitive Planning and Design; France, R.L., Ed.; Lewis: Washington, DC, USA, 2002; pp. 97-124.

27. Fletcher, T.D.; Shuster, W.; Hunt, W.F.; Ashley, R.; Butler, D.; Arthur, S.; Trowadale, S.; Barraud, S.; Semadeni-Davies, A.; Bertrand-Krajewski, J.-L.; et al. SUDS, LID, BMPs, WSUD and more-The evolution and application of terminology surrounding urban drainage. Urban Water J. 2014, 12, 525-542. [CrossRef]

28. Baek, S.S.; Choi, D.H.; Jung, J.W.; Lee, H.J.; Lee, H.; Yoon, K.S.; Cho, K.H. Optimizing low impact development (LID) for stormwater runoff treatment in urban area, Korea: Experimental and modeling approach. Water Res. 2015, 86, 122-131. [CrossRef] [PubMed]

29. Gilroy, K.L.; Mccuen, R.H. Spatio-temporal effects of low impact development practices. J. Hydrol. 2009, 367, 228-236. [CrossRef] 
30. Bedan, E.S.; Clausen, J.C. Stormwater Runoff Quality and Quantity From Traditional and Low Impact Development Watersheds. J. Am. Water Resour. Assoc. 2009, 45, 998-1008. [CrossRef]

31. Lloyd, S.D.; Wong, T.H.F.; Chesterfield, C.J. Water Sensitive Urban Design: A Stormwater Management Perspective; CRC for Catchment Hydrology: CanPrint, Australia, 2002.

32. Sparkman, S.A.; Hogan, D.M.; Hopkins, K.G.; Loperfido, J.V. Modeling Watershed-Scale Impacts of Stormwater Management with Traditional versus Low Impact Development Design. J. Am. Water Resour. Assoc. 2017, 53, 1081-1094. [CrossRef]

33. Jackisch, N.; Weiler, M. The hydrologic outcome of a Low Impact Development (LID) site including superposition with streamflow peaks. Urban Water J. 2017, 14, 143-159. [CrossRef]

34. Ahiablame, L.M.; Engel, B.A.; Chaubey, I. Effectiveness of Low Impact Development Practices: Literature Review and Suggestions for Future Research. Water Air Soil Pollut. 2012, 223, 4253-4273. [CrossRef]

35. Zhang, S.; Meng, Y.; Pan, J.; Chen, J. Pollutant reduction effectiveness of low-impact development drainage system in a campus. Front. Environ. Sci. Eng. 2017, 11, 14. [CrossRef]

36. Liu, H.; Jia, Y.; Niu, C. "Sponge city" concept helps solve China's urban water problems. Environ. Earth Sci. 2017, 76, 473. [CrossRef]

37. Jia, H.; Wang, Z.; Zhen, X.; Clar, M.; Yu, S.L. China's Sponge City construction: A discussion on technical approaches. Front. Environ. Sci. Eng. 2017, 11, 39-49. [CrossRef]

38. Xia, J.; Zhang, Y.Y.; Xiong, L.H.; Shan, H.E.; Wang, L.F.; Zhongbo, Y.U. Opportunities and challenges of the Sponge City construction related to urban water issues in China. Sci. China Earth Sci. 2017, 60, 652-658. [CrossRef]

39. Ma, Y.K.; Gong, M.L.; Zhao, H.T.; Li, X.Y. Influence of low impact development construction on pollutant process of road-deposited sediments and associated heavy metals. Sci. Total Environ. 2018, 613, 1130-1139. [CrossRef] [PubMed]

40. American Public Health Association (APHA). Standard Methods for the Examination of Water and Wastewater; APHA: Washington, DC, USA, 1999.

41. Davis, A.P. Field performance of bioretention: Water quality. Environ. Eng. Sci. 2007, 24, 1048-1064. [CrossRef]

42. Zafra, C.; Temprano, J.; Tejero, I.A. The physical factors affecting heavy metals accumulated in the sediment deposited on road surfaces in dry weather: A review. Urban Water J. 2016, 14, 639-649. [CrossRef]

43. Zhao, H.; Jiang, Q.; Xie, W.; Li, X.; Yin, C. Role of urban surface roughness in road-deposited sediment build-up and wash-off. J. Hydrol. 2018, 560, 75-85. [CrossRef]

44. Sansalone, J.J.; Koran, J.M.; Smithson, J.A.; Buchberger, S.G. Physical Characteristics of Urban Roadway Solids Transported during Rain Events. J. Environ.Eng. 1998, 124, 427-440. [CrossRef]

45. Shaw, S.B.; Parlange, J.Y.; Lebowitz, M.; Walter, M.T. Accounting for surface roughness in a physically-based urban wash-off model. J. Hydrol. 2009, 367, 79-85. [CrossRef]

46. Pitt, R.; Williamson, D.; Voorhees, J. Review of historical street dust and dirt accumulation and washoff data. In Effective Modeling of UrbanWater Systems. Monograph 13; James, W., Irvine, K.N., McBean, E.A., Pitt, R.E., Eds.; National Academies Press: Washington, DC, USA, 2005; pp. 203-246.

47. Yao, L.; Chen, L.; Wei, W. Assessing the effectiveness of imperviousness on stormwater runoff in micro urban catchments by model simulation. Hydrol. Process. 2016, 30, 1836-1848. [CrossRef]

48. Dunne, T.; Leopold, L.B. Water in Environmental Planning; Freeman: Las Vegas, NV, USA, 1978.

49. Rodriguez, F.; Andrieu, H.; Morena, F. A distributed hydrological model for urbanized areas-Model development and application to case studies. J. Hydrol. 2008, 351, 268-287. [CrossRef]

50. United States Environmental Protection Agency (USEPA). Low Impact Development (LID): A Literature Review; United States Environmental Protection Agency: Washington, DC, USA, 2000.

(C) 2018 by the authors. Licensee MDPI, Basel, Switzerland. This article is an open access article distributed under the terms and conditions of the Creative Commons Attribution (CC BY) license (http:// creativecommons.org/licenses/by/4.0/). 